\title{
Internet brand innovation: What is it? What core concepts does it include? Does it affect performance?
}

\begin{tabular}{|c|c|}
\hline \multicolumn{2}{|l|}{$\begin{array}{l}\text { Authors: } \\
\text { Yi-Weng Yang } \\
\text { Xiao-Bo Tao }{ }^{1} \\
\text { Jian-Bo Tu } \\
\text { Pei Liu }{ }^{2} \\
\text { Ji-Peng }\end{array}$} \\
\hline \multicolumn{2}{|c|}{$\begin{array}{l}\text { Affiliations: } \\
{ }^{1} \text { Department of Business } \\
\text { Administration, School of } \\
\text { Economics and Management, } \\
\text { North China University of } \\
\text { Technology, Beijing, China }\end{array}$} \\
\hline \multicolumn{2}{|c|}{$\begin{array}{l}{ }^{2} \text { Department of Marketing, } \\
\text { School of Business, Central } \\
\text { University of Finance and } \\
\text { Economics, Beijing, China }\end{array}$} \\
\hline \multicolumn{2}{|c|}{$\begin{array}{l}{ }^{3} \text { Department of Innovation } \\
\text { and Strategic Management, } \\
\text { School of Business } \\
\text { Administration, Xinjiang } \\
\text { University of Finance and } \\
\text { Economics, Urumchi, China }\end{array}$} \\
\hline \multicolumn{2}{|c|}{$\begin{array}{l}\text { Corresponding author: } \\
\text { Xiao-Bo Tao, } \\
\text { dicuike@126.com }\end{array}$} \\
\hline \multicolumn{2}{|c|}{$\begin{array}{l}\text { Dates: } \\
\text { Received: } 13 \text { Aug. } 2020 \\
\text { Accepted: } 24 \text { Mar. } 2021 \\
\text { Published: } 24 \text { May } 2021\end{array}$} \\
\hline \multicolumn{2}{|c|}{$\begin{array}{l}\text { How to cite this article: } \\
\text { Yang, Y-W., Tao, X-B., Tu, J-B., } \\
\text { Liu, P., \& Li, J-P. (2021). } \\
\text { Internet brand innovation: } \\
\text { What is it? What core } \\
\text { concepts does it include? } \\
\text { Does it affect performance? } \\
\text { South African Journal of } \\
\text { Business Management, 52(1), } \\
\text { a2306. https://doi.org/ } \\
\text { 10.4102/sajbm.v52i1.2306 }\end{array}$} \\
\hline \multicolumn{2}{|c|}{$\begin{array}{l}\text { Copyright: } \\
\text { (C) 2021. The Authors } \\
\text { Licensee: AOSIS. This } \\
\text { is licensed under the } \\
\text { Creative Commons } \\
\text { Attribution License. }\end{array}$} \\
\hline \multicolumn{2}{|l|}{ Read online: } \\
\hline 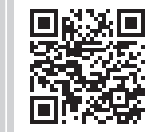 & $\begin{array}{l}\text { Scan this QR } \\
\text { code with your } \\
\text { smart phone or } \\
\text { mobile device } \\
\text { to read online. }\end{array}$ \\
\hline
\end{tabular}

Purpose: This article investigates the definition and core concepts of Internet brand innovation alongside their influence on performance.

Design/methodology/approach: A combined qualitative and quantitative design was used. Interviews of 42 Internet companies were conducted. Over 200 speeches of entrepreneurs were collated and a content analysis and case study of the data were conducted. A total of 309 questionnaires of Honor's employees were collated. Partial least squares structural equation modelling was employed for data analysis.

Findings: Internet brand innovation refers to companies carrying out Internet-based brand innovations, which results in fundamental changes to existing products, marketing or business model practices. This process involves five core concepts with the following influences on performance: Internet information application mediates the relationship between Internet information acquisition and performance. Interaction and cooperation through platform positively influences performance. Internet advanced technology application and Internet strategic capability can strengthen the positive effects of Internet information acquisition on mining potential demands.

Practical implications: Internet companies should explore new avenues, focus on their main channels for conducting continuous brand innovations and build win-win ecosystems to cocreate value with stakeholders.

Originality/value: This article proposes an interpretation of a new concept - Internet brand innovation. It reveals ways in which companies can conduct Internet brand innovation to improve performance. Furthermore, for Internet companies, mining potential demands is more important than meeting existing demands and disruptive innovation is more important than incremental innovation.

Keywords: Internet brand innovation; Internet companies; innovation performance; product innovation; marketing innovation; business model innovation; information acquisition; strategic capability.

\section{Introduction}

In recent years, many companies have conducted Internet brand innovation and achieved rapid expansion and high performance. For instance, Xiaomi has encouraged users to fully participate in new product development, sales and brand communication. The company also created a new category of 'Internet mobile phone' and reached the top of China's smartphone market in 2014. DiDi launched an online ride-hailing business model, which covered more than 400 cities in China, has 450 million users, more than 25 million daily orders and market share of over $90 \%$. From its establishment in 2012 to September 2020, DiDi has completed 20 rounds of financing, obtaining over $\$ 20$ billion and a valuation of more than $\$ 60$ billion.

Internet brand innovation is becoming increasingly important in practice; however, scholars have not conducted much research on the topic. Amongst the few existing studies, a consensus on the concept of brand innovation has yet to be reached. Therefore, our first research problem is as follows: 'What is Internet brand innovation?' Some scholars have studied the influencing factors of social media brand innovation (Nguyen et al., 2015) and others have researched the influence of brand innovation on market performance (Grigoriou, Davcik, \& Sharma, 2016; Nguyen, Yu, Melewar, \& Gupta, 2016), but none have established a relationship between Internet brand innovation and performance. Core concepts related to social media brand innovation include knowledge acquisition from social media, market orientation and social media strategic capability (Nguyen et al., 2015). Social media is one kind of Internet platform. Thus, our second group of 
research problems comprises the following questions: 'Does Internet brand innovation include similar core concepts?'; 'Are there any other core concepts included?' and 'What is the influencing mechanism of these core concepts on performance?'

We aim to answer these questions through a combined qualitative and quantitative design for the following reasons. Firstly, qualitative researchers claim that the understanding of organisational phenomena must be based on researchers' subjective interpretation (Lee, 1999). Secondly, qualitative studies pay close attention to understanding the organisational process rather than predicting organisational performance, whilst quantitative studies do the opposite (Symon \& Cassell, 1997). Thirdly, qualitative studies usually focus on the identification and classification of organisational phenomena, which involves content analysis and classified variables (category) or ordinal variables (quantity), whilst quantitative studies involve an accurate description of organisations (Kvale, 1996).

We propose a subjective interpretation of a new concept: Internet brand innovation. We also pay attention to process, models (category) and core concepts (quantity) of Internet brand innovation. Furthermore, we focus on the influencing mechanism of these core concepts on performance (accurate description).

Therefore, we will conduct a combined qualitative and quantitative study using two-stage design method (Creswell, 1998). The two-stage design method possesses the advantages of qualitative and quantitative research. Qualitative research can be used to confirm variables and processes, whilst the least-squares method from quantitative studies can determine the influence of specific predicted variables on dependent variables (Lee, 1999). Firstly, we conduct a qualitative study to propose the concept and core variables of Internet brand innovation and construct our research model. Secondly, we perform quantitative research. Data are collected through questionnaires and analysed by partial least squares structural equation modeling to empirically test the influencing mechanism of these core concepts on performance.

\section{Literature review}

\section{The concept of brand innovation}

Some scholars equated brand innovation with product innovation (Beverland, Napoli, \& Farrelly, 2010), especially new product development (Slotegraaf \& Pauwels, 2008). However, the concept of brand is far more meaningful than product (Keller, 2013). For example, the 'Apple' brand comprises not only iPhones but also its innovative spirit, its positive associations and the unique emotional experience that it creates. Innovations are mainly driven by market demand and technological advances (Salavou \& Lioukas, 2003; Stock, Six, \& Zacharias, 2013). So, some scholars suggested that brand innovation included two categories: marketing innovation and product or technology innovation (Nguyen et al., 2015). For example, Coca-Cola's 'nickname bottle' integrated marketing communication activities belong to marketing innovation, whereas WeChat's red envelope constitutes product innovation ('red envelope' refers to money given to children as a Chinese New Year gift. Consumers can send red envelopes, snatch red envelopes and withdraw money in WeChat App).

However, in the Internet era, many companies have achieved success not through marketing innovation or product or technology innovation but through business model innovation (Spiegel et al., 2016). For example, the Chinese electric vehicle startup Nio is winning over more consumers through 'user enterprise'. Many famous entrepreneurs also mentioned the importance of business model innovation when talking about brand innovation. For instance, the founder of Xiaomi believed that 'brand innovation needs to seek breakthroughs in three directions: firstly, technology breakthroughs; secondly, marketing breakthroughs; thirdly, business model breakthroughs'. Giant Interactive Group's founder said the following: 'If a brand wants to be built to last, it must continuously carry out business model innovation'. Based on management practices and entrepreneurs' viewpoints, should Internet brand innovation also include the category of business model innovation?

Another focus of controversial issues on brand innovation is as follows: to what extent does innovation affect existing practices and markets to be counted as brand innovation? Some scholars have held that all innovation activities (from minor innovations, such as product packaging, to major innovations that overturn markets) could be considered brand innovation (Chimhundu, Hamlin, \& McNeill, 2010). However, other scholars have argued that it only applies to innovations that caused fundamental changes to existing practices and markets (Nguyen et al., 2015).

Thus, our first group of research problems constitutes the following questions: 'What is Internet brand innovation?' and 'What categories of models does it include?'

\section{Core concepts involved in the process of brand innovation and their influencing mechanism on performance}

Some scholars have proposed that brand innovation is a process (Sammour, Chen, Balmer, Botchie, \& Faraday, 2020) that involves a series of core concepts and found three concepts that are involved in social media brand innovation: knowledge acquisition, knowledge application (market orientation) and strategic capability (Nguyen et al., 2015). However, the aforementioned research did not explore the relationship between knowledge acquisition, knowledge application and performance or the impact of social media brand innovation on performance. Social media is one kind of Internet platform, so we speculate that Internet brand innovation also involves three core concepts: information acquisition, information application and strategic capability. The relationship between information acquisition, information application and performance is an 
important issue that absorptive capacity theory focuses on. Therefore, we introduce the theory (Camisón \& Forés, 2010; Cohen \& Levinthal, 1990; Zahra \& George, 2002) to further analyse the relationship amongst Internet information acquisition, information application and performance.

\section{Absorptive capacity theory}

Absorptive capacity theory examines the process of how companies identify the value of new knowledge, absorb it and apply it to achieve organisational goals (Cohen \& Levinthal, 1990). Based on absorptive capacity theory, scholars have explored the relationship amongst knowledge acquisition, knowledge application and performance. Zahra and George (2002) proposed four key dimensions of absorptive capacity: acquisition, assimilation, transformation and exploitation. The former two are 'potential' absorptive capacity, whilst the latter two are 'realised' absorptive capacity. The four-dimensional view of absorptive capacity has been widely accepted by scholars (Camisón \& Forés, 2010). Based on this theory, scholars have explored the relationship between knowledge acquisition, knowledge application and performance. Zahra and George (2002) proposed an absorptive capacity model whose main influencing path is knowledge sources and complementarity $\rightarrow$ absorptive capacity (potential absorptive capacity $\rightarrow$ realised absorptive capacity) $\rightarrow$ competitive advantage (strategic flexibility, innovation and performance). GarcíaSánchez, García-Morales and Bolívar-Ramos (2017) studied the information and communication technology (ICT) industry and found that top management support for ICT positively affected the knowledge management process (knowledge acquisition $\rightarrow$ knowledge transfer $\rightarrow$ knowledge utilisation) and further affected organisational performance.

\section{Main influencing path}

Considering absorptive capacity theory and related studies, we speculate that when companies perform Internet brand innovation, the main influencing path is Internet information acquisition $\rightarrow$ Internet information application $\rightarrow$ performance. The Internet information application includes two types of guidance: one is meeting existing demands and the other is mining potential demands (Marvel \& Lumpkin, 2007). 'Meeting existing demands' refers to companies understanding and meeting demands expressed by consumers based on information acquired online (Codron, Grunert, Giraud-Heraud, Soler, \& Regmi, 2005; LeBlanc, Heinicke, \& Baker, 2012); 'mining potential demands' refers to companies mining and leading potential demands that consumers are not aware of based on information acquired online (Song \& Liu, 2017; Van Nguyen, Zhou, Chong, Li, \& Pu, 2020).

Based on the preceding discussion, the following hypotheses are proposed:

H1: Internet information application mediates the relationship between Internet information acquisition and performance of Internet brand innovation.
H1a: Meeting existing demands mediates the relationship between Internet information acquisition and performance of Internet brand innovation.

H1b: Mining potential demands mediates the relationship between Internet information acquisition and performance of Internet brand innovation.

\section{Moderating role of internet strategic capability}

Internet strategic capability is a company's ability to integrate information acquired online with internal resources to apply to brand innovations and make innovations that are consistent with the company's strategic directions (Nguyen et al., 2015; Teece, 2007). The sustainable competitive advantage of a company comes from resources owned by the company and the company's strategic capability to integrate and transform resources (Teece, 2007). Strong Internet strategic capability provides a company with a management mechanism to support and enhance its unique capabilities. Through this mechanism, the company can effectively apply information and resources acquired from the Internet consistently with its strategic goals (Yu, Chen, Nguyen, \& Zhang, 2014), accurately formulate Internet innovation strategies and effectively conduct Internet brand innovation (Danneels, 2002). Companies with strong Internet strategic capability are characterised by speed and flexibility to cope with fierce competition in the Internet era and the strategic vision to quickly identify new business opportunities and potential threats. On one hand, it drives companies to continuously apply valuable information acquired from the Internet to conduct brand innovation. On the other hand, it makes companies focus on the main channels to conduct brand innovation and avoid blind innovation to reduce risks associated with brand innovation.

Based on the preceding discussion, the following hypotheses are proposed:

H2: Internet strategic capability positively moderates the relationship between Internet information acquisition and Internet information application.

H2a: Internet strategic capability positively moderates the relationship between Internet information acquisition and meeting existing demands.

H2b: Internet strategic capability positively moderates the relationship between Internet information acquisition and mining potential demands.

As social media is only one kind of Internet platform, Internet brand innovation is more meaningful than social media brand innovation. Therefore, in addition to Internet information acquisition, information application and strategic capabilities, Internet brand innovation may include other core concepts that need to be explored.

Therefore, our second group of research problems is as follows: 'What are the core concepts involved in the process of Internet brand innovation?' and 'What is the influencing mechanism of these core concepts on performance?' 
To answer the aforementioned research problems, a combined qualitative and quantitative investigation is conducted.

\section{Qualitative research Text collection}

We were writing an annual report on development of e-commerce with the support of a Chinese chamber of commerce, so we got the opportunity to conduct surveys of its member companies. From May to June 2019, we conducted in-depth interviews with founders, managers and employees of 42 Internet companies in China such as Fabest care, Like and Emao. We designed the interview outline based on the problems identified from the literature review. The questions were as follows: (1) Describe the general condition of your company including history and development status, industry competition, Internet strategy and its implementation. (2) What is brand innovation? (3) What aspects are included in brand innovation? (4) What is Internet brand innovation? (5) What models are included in Internet brand innovation? 6) How does your company conduct Internet brand innovation? (7) What factors affect your company's performance of Internet brand innovation? We conducted face-to-face semi-structured interviews in which the contents were recorded with the consent of interviewees and then transcribed. The contents of the interviews are restricted by confidentiality agreements.

Becuase of limited resources, our interviews lack first-hand data on the founders and senior executives of the largest Internet companies such as Apple, Huawei and Alibaba. To avoid omitting important viewpoints, we searched for and found over 200 interviews, reports and speeches of famous entrepreneurs such as Steve Jobs, Ren Zheng-Fei and Jack Ma online using keywords such as 'Internet + brand innovation + performance'.

By combining the first-hand and second-hand data, we built a database of nearly 900000 Chinese characters.

\section{Content analysis}

We used ROST CM 6.0 software for content analysis. Firstly, we performed word segmentation. Secondly, we analysed word frequency.

The word frequency rankings of the top keywords were as follows: Internet (at 4543), innovation (3262), model (1750), marketing (1640), brand (1614) and product (1270). From the perspective of the number of keywords and their correlation, including our subjective interpretation of interview data, we find that Internet brand innovation includes three models: business model innovation, marketing innovation and product innovation.

Meanwhile, when discussing Internet brand innovation, many entrepreneurs emphasised the importance of fundamental changes to existing practices and markets. For example, 360 Company's founder pointed out that in the Internet era, only disruptive innovation can succeed. Sina's CEO stressed that in the Internet field, if you do not disrupt yourself, you will be disrupted. Internet brand innovation must have courage to disrupt itself. A medium-sized Internet company's CEO mentioned that Internet brand innovation is actually a kind of innovation of 'Internet plus practices', which combines the existing practice results with Internet thinking to carry out mixed changes and disruptive reforms. Another CEO of a small Internet company observed that the biggest difference between Internet brand innovation and ordinary brand innovation lies in its disruption. Thus, only innovations that result in fundamental changes to existing practices and markets constitute Internet brand innovations.

In summary, we propose the following definition of Internet brand innovation: Companies carry out brand innovations based on the Internet, which result in fundamental changes to existing product, marketing or business model practices.

Furthermore, we conducted semantic network and social network analysis in five steps: (1) extracting high frequency words; (2) filtering nonsense words; (3) extracting row features; (4) building network; and (5) building matrix. Then, we drew the collinear matrix of keywords, as shown in Figure 1.

Figure 1 shows that Internet brand innovation mainly includes three models: business model innovation, marketing innovation and product innovation. Simultaneously, based on the correlation between keywords and our subjective interpretation of interview data, we found that Internet brand innovation included five core concepts: Internet information acquisition, Internet information application, Internet strategic capability, Internet advanced technology application and interaction and cooperation through platform.

\section{Case study}

We collected typical cases and summarised representative viewpoints to test the external validity of the five core concepts of Internet brand innovation, as shown in Table 1.

As shown in Table 1, these four core concepts (Internet information acquisition, information application, advanced technology and interaction and cooperation through platform) all seem to be related to performance. In the literature review, we put forward the main influencing path of 'Internet information acquisition $\rightarrow$ Internet information application $\rightarrow$ performance' and analysed the moderating effect of Internet strategic capability. Subsequently, based on the results of content analysis and case study, we deduced the relationship between Internet advanced technology application, interaction and cooperation through platform and performance to build our final research model.

\section{Hypothesis development}

\section{Moderating the role of internet advanced technology application}

During our interviews, many interviewees emphasised the important impact of Internet advanced technology application during the process of Internet brand innovation. For example: 


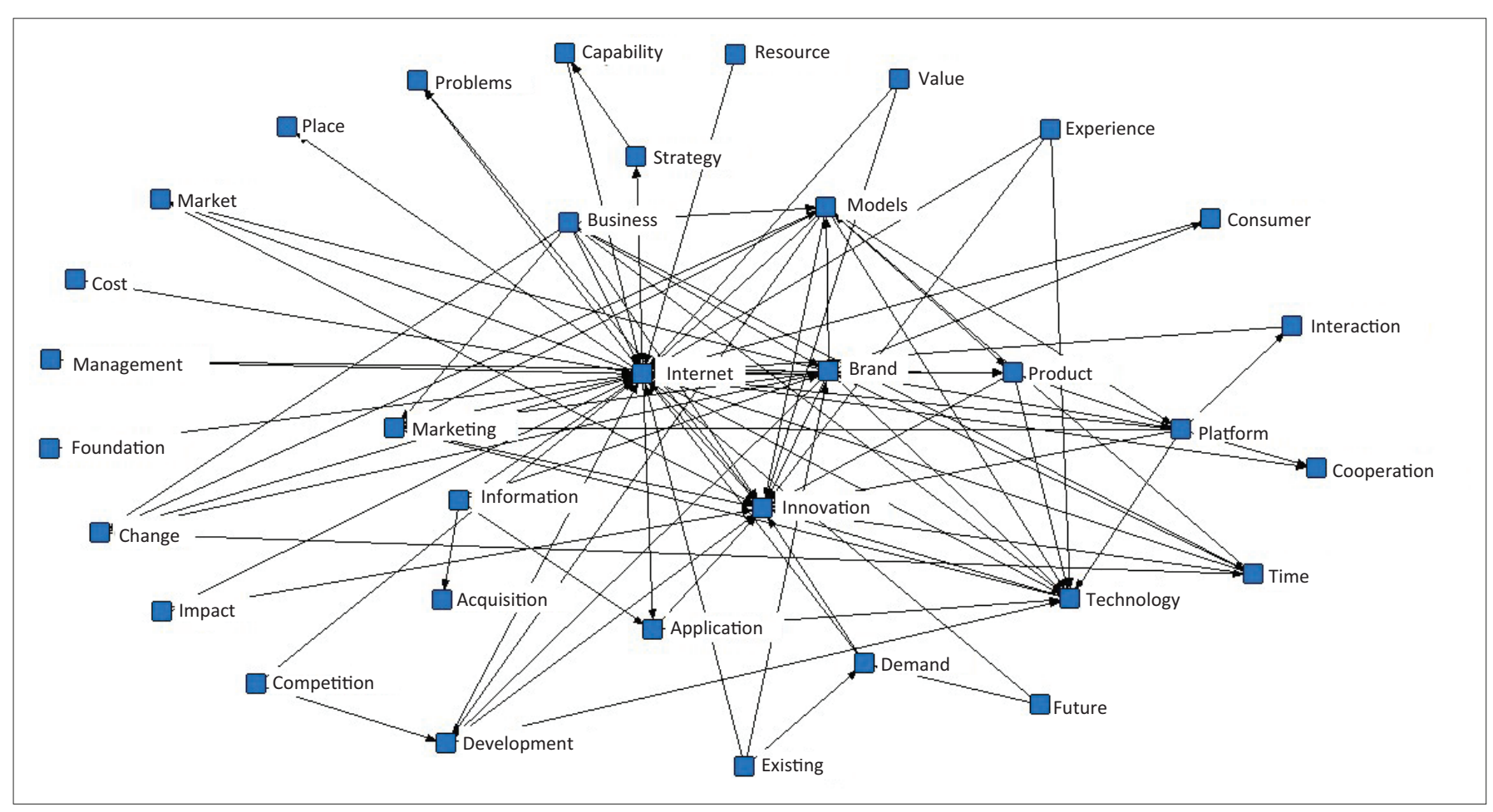

Note: All keywords have been translated into English.

FIGURE 1: Collinear matrix of keywords.

'Internet brand innovation is closely related with progress of science and technology, such as biological recognition, neural network and artificial intelligence technology. Using these advanced technologies, companies can apply information acquired from Internet better.' (Veteran Internet Practitioner)

According to a Xiaomi manager, advanced technology itself may not directly affect the performance of Internet brand innovation. Companies need to use advanced technology to better apply information acquired from Internet. These views suggest that Internet advanced technology application may not directly affect performance, but may enhance the impact of Internet information acquisition on Internet information application.

Based on the preceding discussion, the following hypotheses are proposed:

H3: Internet advanced technology application positively moderates the relationship between Internet information acquisition and Internet information application.

H3a: Internet advanced technology application positively moderates the relationship between Internet information acquisition and meeting existing demands.

H3b: Internet advanced technology application positively moderates the relationship between Internet information acquisition and mining potential demands.

\section{Important impact of interaction and cooperation through platform}

Many entrepreneurs mentioned the importance of cooperating with business partners through platform to create win-win results when carrying out Internet brand innovation. For example, Haier's CEO said that in the
Internet era, we have changed our suppliers from game relationships to partnerships and it is not fixed, anyone who does well can participate in our platform. Another said that:

'Huajiao LIVE implements the open platform strategy, launching a variety of forms of cooperation with vertical companies such as Tuniu.com, BitAuto and Baihe.com. From 'live streaming + e-commerce' to 'live streaming + tourism', from 'live streaming + agriculture' to 'live streaming + public welfare', these kinds of crossover cooperation have provided rich and diversified contents for Huajiao LIVE and improved its innovation performance.' (Huajiao LIVE Manager)

Many entrepreneurs also mentioned the important impact of interaction through platform on performance. For example, according to the chairman of Alibaba's academic committee, only when companies establish a long-term dynamic interactive relationship with users can they get rapid feedbacks and then continuously improve brand performance. Xiaomi's co-founder noted that the Internet era is not an era of simply selling products but selling a sense of participation. Interacting with users is the real secret behind Xiaomi's high performance.

Based on the preceding discussion, the following hypothesis is proposed:

H4: Interaction and cooperation through platform positively affect the performance of Internet brand innovation.

In summary, we comprehensively consider the results of literature reviews and qualitative research to construct our research model, as shown in Figure 2. 
TABLE 1: Core concepts, typical cases and representative viewpoints.

\begin{tabular}{ll}
\hline Core concepts & Definitions \\
\hline Internet information & $\begin{array}{l}\text { Companies acquire information } \\
\text { from users, partners and } \\
\text { competitors through various } \\
\text { Internet-based platforms. }\end{array}$
\end{tabular}

Typical cases

360 Total Security Company acquires user information online through 360 Total Security, 360 Security Browser, and other software. Furthermore, 360 Company acquire user information and monitors competitors and user feedback through 360's bulletin board system, microblog and other Internet platforms, mastering a large volume of valuable information.

Internet information application: Meetin existing demands

Companies understand and mee existing demands expressed by consumers based on information acquired online.

Internet information application: Mining

Companies mine and lead potential demands that consumers are not aware of based on information acquire online.

Huajiao LIVE found three pain points for users to watch live videos on mobile phones. Firstly, users often miss live videos. Secondly, users do not have enough mobile phon flows. Thirdly, users do not have enough mobile phone internal memory. Thus, Huajiao developed three corresponding functions to meet these existing demands. Firstly, playback of live video so that missed live videos can be watched later. Secondly, automatically compressing video sizes to save user flows. Thirdly, cloud storage to free up the internal memory of mobile phones. Having met existing demands, Huajiao has become one of the largest mobile social broadcast platforms in China.

From iPods to iPhones and iPads, Apple has launched several revolutionary products that have 'changed the world', constantly mining and guiding consumers' demands. Apple leads the trend of global brand innovation, ranking at the top of many brand value lists.

Internet advanced technology application

Companies apply advanced technologies to conduct brand innovations based on the Internet.

Toutiao applies advanced artificial intelligence and machine learning technology to personalise content. Its personalised news recommendation system enables it to understand users well and recommend news with great accuracy, thereby improving users' experience and great accuracy, thereby improving users experience and users and 140 million active users, with average daily usage time exceeding $76 \mathrm{~min}$.

Internet strategic capability

The capability of companies to integrate information acquired online with internal resources to apply to brand innovations and apply to brand innovations and make brand innovations that strategic directions. telizontal expansion. It has become the world's largest
Positive Case. Huawei strengthens strategic concentration, carrying out innovations on the main channels and battlefields. Huawei encourages innovation and deep development but opposes blind innovations and horizontal expansion. It has become the world's lar second quarter of 2020 its smartphone shipments ranked No. 1 globally.

Negative Case. LeEco started as a video website and developed into a diversified company covering TV, mobile phone, automobile, finance, sports, movies and mobile phone, auts. How other businesses. However, owing to rush advances and have a leadi business it entered.

When Xiaomi is developing new products, thousands of When Xiaomi is Xiami is prome up with ideas enthusiastically. When Xiamis is promoting products, millions of consumers create buzz. When Xiaomi's products have been sold, millions of consumers actively participate in word-of mouth communication and feedback of products. Xiaomi won No. 1 position in China's smartphone market
in 2014.

\section{Representative viewpoints}

'360 Company conducts deep analyses on users' information constantly to form a huge big data system spanning PCs and mobile phones.' (Zhou Hong-Yi 360 Company's founder)

360 Company monitors competitors constantly to mine what competitors don't have, as well as monitors users' feedbacks constantly to provide what users really need and give the best to users.' (360 Company's content specialist)

'Huajiao has been committed to solving users' pain points of making friends and improving users' experience.' (Huajiao's chief technical officer) 'Huajiao developed a series of targeted functions for solving users' pain points, such as playback, flow saving, and cloud storage, thus improved users' experiences.' (Huajiao's video auditor)

'Why is Huajiao so popular? The essential reason is that it meets existing demands of different crowds with massive and high-quality contents.' (an Internet expert)

'A lot of times, people don't know what they want until you show it to them.' (Steve Jobs)

'Some people say, 'Give the customers what they want.' But that's not my approach. Our job is to figure out what they're going to want before they do.' (Steve Jobs) 'You can't cater to the needs of users, but rather beyond the needs of users and tap into the deepest needs of their hearts.' (Steve Jobs)

'As a new generation of artificial intelligence technology company, Toutiao is an active practitioner of artificial intelligence technology and its application.' (Zhang Yi-Ming Toutiao's founder)

'Algorithm and technology have become the core 'Algorithm and technology have becoms.' (Toutiao's president of technology)

'To become a leader, we must strengthen strategic concentration, concentrate our forces on the main channels and battlefields to fight wars of annihilation and occupy high ground' (Ren Zheng-Fei Huawei's founder)

'Huawei has invested the biggest strength in the world

to carry out innovations, but Huawei opposes blind innovations.' (Huawei's founder)

'We ran madly and blindfoldedly, as well as burned our cash in pursuit of scale; our globalisation battle line has stretched too long all at once.' (Jia Yue-Ting LeEco's founder)

'We can at once.' (Jia Yue Ting LeEco's founder) We cannot concentrate our strength on one single opened up territory after territory, we are still short of provisions in time and our momentum is clearly provisions in time and our mor
weakening.' (LeEco's founder)

'Xiaomi model is a "user-engaged Internet development model." "A sense of engagement" is the biggest secret of Xiaomi's success.' (Lei Jun Xiaomi's founder)

'Xiaomi has been willing to cooperate with major

internet platforms. How to carry out cooperation? Firstly, internet platforms. How to carry out cooperation? Firstly, secondly, facing competition and cooperation with an secondly, facing competition and cooper
open mind.' (Xiaomi's vice president)

\section{Quantitative research}

\section{Methodology}

\section{Questionnaire design}

Honor was the fastest-growing smartphone brand in the world in 2018 and has become the leader in the sales volume and revenues of Internet mobile phones in China. Therefore, we select Honor as our research object. Our questionnaires include seven parts: Internet information acquisition (Nguyen et al., 2016), Internet advanced technology application (Choi, Lee, \& Yoo, 2010), Internet strategic capability (Nguyen et al., 2016), Internet information application (Narver, Slater, \& Maclachlan, 2004), interaction and cooperation through platform (Foss, Laursen, \& Pedersen, 2011; Kim \& Han, 2014), performance of Internet brand innovation (Nguyen et al., 2016; Nieves \& DiazMeneses, 2016), and personal information. All items except personal information are measured by a seven-point Likert scale.

\section{Data collection}

As questions in the questionnaires are difficult for ordinary consumers to answer our questionnaires were mainly conducted for employees of Honor. A member of our research group was an employee of Honor. We asked her to send the questionnaires to her colleagues. After obtaining the consent of a head of the relevant department and signing a confidentiality agreement, we asked employees of Honor to fill in the questionnaires. The questionnaires were distributed from July to August in 2019, and 309 valid questionnaires were collected. Table 2 summarises the respondents' demographics. Almost half of the participants (44.01\%) were female, $35.60 \%$ were under 30 years, $45.95 \%$ were research and development (R\&D) staff. About $61.49 \%$ held a bachelor's degree, whilst $29.77 \%$ held a master's or above degree. The chief strategy and brand development officer of Honor said $52 \%$ of Honor's employees were female, and $37 \%$ were under 30 years old, which was close to our data. As an Internet 


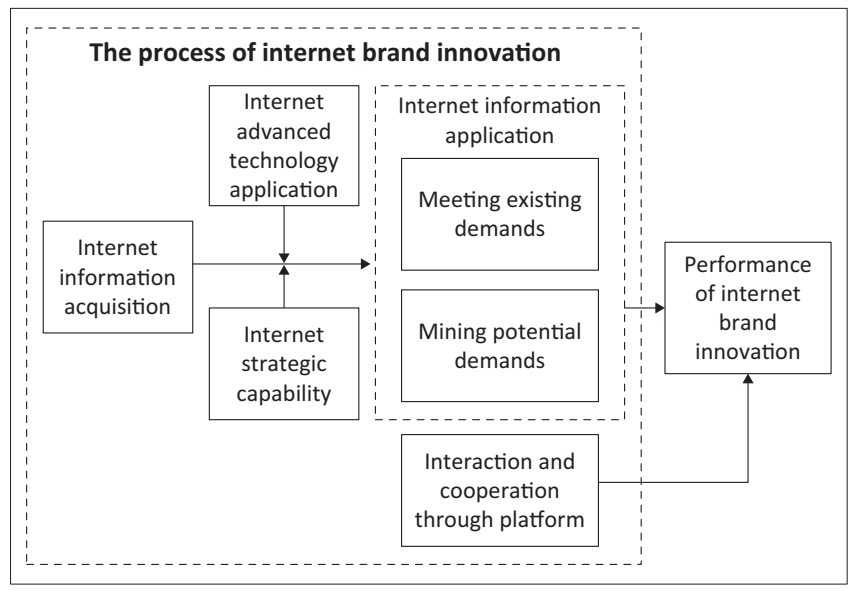

FIGURE 2: Research model.

TABLE 2: Respondent's profile $(n=309)$.

\begin{tabular}{lcc}
\hline Demographic information & Frequency & $\%$ \\
\hline Gender & 173 & 55.99 \\
Male & 136 & 44.01 \\
Female & & \\
Age & 110 & 35.60 \\
Under 30 & 169 & 54.69 \\
30-50 & 30 & 9.71 \\
Over 50 & & \\
Education & 27 & 8.74 \\
High school & 190 & 61.49 \\
Bachelor's degree & 92 & 29.77 \\
Master's degree and above & & \\
Position & 142 & 45.95 \\
Research and development & 15 & 4.85 \\
Sales & 69 & 22.33 \\
Delivery and service & 19 & 6.15 \\
Strategy and marketing & 25 & 8.03 \\
Manufacturing and supply chain & 39 & 12.69 \\
Others & & \\
\hline
\end{tabular}

mobile phone brand, employees of Honor were relatively young. As a high-tech enterprise, employees of Honor were highly educated. Honor is famous for its large investment in R\&D, so the proportion of its R\&D employees was relatively high.

\section{Statistical analysis method}

Partial least squares structural equation modeling (PLSSEM) was used to analyse the data. According to our research model (Figure 2) and relevant requirements (Hair, Hult, Ringle, \& Sarstedt, 2014), the minimum sample size is 124. Our valid sample size is 309 , which meets the requirements.

\section{Results}

\section{Outer model}

\section{Reliability test}

Factor loading of each indicator is higher than the restricted level of 0.7. Cronbach's alpha and Composite Reliability (CR) of each construct are higher than the restricted level of 0.7, thereby indicating that our scales have good reliability (Hair et al., 2014), as shown in Table 3.

\section{Validity test}

Convergent validity: The Average Variance Extracted (AVE) values of all constructs are higher than the restricted level of 0.5 , which indicates that our scales have good convergent validity (Hair et al., 2014), as shown in Table 4.

Discriminant validity: The square root of the AVE of each construct is higher than its highest correlation with other constructs, which indicates that our scales have good discriminant validity (Hair et al., 2014), as shown in Table 4.

\section{Common method bias test}

We attempted to reduce the potential effects of response pattern biases by incorporating reverse-coded items on our questionnaires (Hinkin, 1995). Furthermore, we used other two methods to test common method biases. The first method is Harman's single-factor test. Results of exploratory factor analysis show that the variance extracted by the first unrotated factor is $49.786 \%$, which is lower than the restricted level of $50 \%$. The second method is correlation test. The largest correlation coefficient between constructs is 0.794 (Table 4), which is lower than the restricted level of 0.9. The preceding results show that common method bias is not a serious threat in this study (Podsakoff, Mackenzie, Lee, \& Podsakoff, 2003).

\section{Multicollinearity test}

We used two steps to test multicollinearity (Hair et al., 2014). The first step is assessing the level of collinearity in the formative measurement model. Our findings show that the highest Variance Inflation Factor (VIF) is 2.691, which is lower than the restricted level of 5 . The second step is analysing the significance of outer weights. We run the bootstrapping procedure with 5000 bootstrap samples and the results show that the outer weights of all items are significant at the level of $0.05(\alpha=0.05)$. The results show that the multicollinearity problem is not serious (Hair et al., 2014).

\section{Inner model}

\section{Path analysis and hypothesis testing}

We run the bootstrapping procedure with 5000 bootstrap samples. The results are presented in Table 5.

As shown in Table 5, interaction and cooperation through platform significantly and positively affect the performance of Internet brand innovation, indicating that $\mathrm{H} 4$ is supported.

\section{Mediator analysis}

We conducted Sobel, Aroian and Goodman tests to conduct mediator analysis. The results are shown in Table 6.

As shown in Table 6, meeting existing demands mediates the relationship between Internet information acquisition and performance of Internet brand innovation, indicating that $\mathrm{H} 1 \mathrm{a}$ is supported; mining potential demands mediates the 
TABLE 3: Reliability and convergent validity test.

\begin{tabular}{|c|c|c|c|c|c|}
\hline Latent variable & Indicators & Loadings & Cronbach's $\alpha$ & CR & AVE \\
\hline \multirow{5}{*}{$\begin{array}{l}\text { Internet Information } \\
\text { acquisition }\end{array}$} & - & - & 0.848 & 0.898 & 0.688 \\
\hline & IIA1 & 0.806 & - & - & - \\
\hline & IIA2 & 0.860 & - & - & - \\
\hline & IIA3 & 0.840 & - & - & - \\
\hline & IIA4 & 0.809 & - & - & - \\
\hline \multirow{3}{*}{$\begin{array}{l}\text { Internet advanced } \\
\text { technology } \\
\text { application }\end{array}$} & - & - & 0.804 & 0.911 & 0.836 \\
\hline & IATA1 & 0.916 & - & - & - \\
\hline & IATA2 & 0.912 & - & - & - \\
\hline \multirow{5}{*}{$\begin{array}{l}\text { Internet strategic } \\
\text { capability }\end{array}$} & - & - & 0.867 & 0.910 & 0.715 \\
\hline & ISC1 & 0.839 & - & - & - \\
\hline & ISC2 & 0.853 & - & - & - \\
\hline & ISC3 & 0.852 & - & - & - \\
\hline & ISC4 & 0.838 & - & - & - \\
\hline \multirow{4}{*}{$\begin{array}{l}\text { Meeting existing } \\
\text { demands }\end{array}$} & - & - & 0.812 & 0.889 & 0.727 \\
\hline & MED1 & 0.837 & - & - & - \\
\hline & MED2 & 0.912 & - & - & - \\
\hline & MED3 & 0.807 & - & - & - \\
\hline \multirow{5}{*}{$\begin{array}{l}\text { Mining potential } \\
\text { demands }\end{array}$} & - & - & 0.869 & 0.911 & 0.719 \\
\hline & MPD1 & 0.801 & - & - & - \\
\hline & MPD2 & 0.857 & - & - & - \\
\hline & MPD3 & 0.863 & - & - & - \\
\hline & MPD4 & 0.869 & - & - & - \\
\hline \multirow{8}{*}{$\begin{array}{l}\text { Interaction and } \\
\text { cooperation } \\
\text { through platform }\end{array}$} & - & - & 0.900 & 0.921 & 0.624 \\
\hline & ICP1 & 0.777 & - & - & - \\
\hline & ICP2 & 0.791 & - & - & - \\
\hline & ICP3 & 0.797 & - & - & - \\
\hline & ICP4 & 0.822 & - & - & - \\
\hline & ICP5 & 0.812 & - & - & - \\
\hline & ICP6 & 0.780 & - & - & - \\
\hline & ICP7 & 0.750 & - & - & - \\
\hline \multirow{7}{*}{$\begin{array}{l}\text { Performance of } \\
\text { internet brand } \\
\text { innovation }\end{array}$} & - & - & 0.886 & 0.914 & 0.639 \\
\hline & PIBI1 & 0.763 & - & - & - \\
\hline & PIBI2 & 0.835 & - & - & - \\
\hline & PIBI3 & 0.812 & - & - & - \\
\hline & PIBI4 & 0.835 & - & - & - \\
\hline & PIBI5 & 0.790 & - & - & - \\
\hline & PIBI6 & 0.755 & - & - & - \\
\hline
\end{tabular}

relationship between Internet information acquisition and the performance of Internet brand innovation, indicating that $\mathrm{H} 1 \mathrm{~b}$ is supported.

\section{Moderator analysis}

SmartPLS v3.2.7 software was used to create moderating effects 1 and 2 (Hair et al., 2014), which take Internet advanced technology application as the moderator, Internet information application as the independent variable and meeting existing demands and mining potential demands as dependent variables. We also generate moderating effects 3 and 4, which take Internet strategic capability as the moderator, Internet information application as the independent variable and meeting existing demands and mining potential demands as dependent variables. We run the bootstrapping procedure with 5000 bootstrap samples. The results are presented in Table 7.

As shown in Table 7, the moderating effect of Internet strategic capability on the relationship between Internet
TABLE 4: Discriminant validity test.

\begin{tabular}{lccccccc}
\hline Variable & ICP & IIA & ISC & IATA & PIBI & MPD & MED \\
\hline ICP & $0.790 \dagger$ & - & - & - & - & - & - \\
IIA & 0.583 & $0.829 \dagger$ & - & - & - & - & - \\
ISC & 0.779 & 0.596 & $0.846 \dagger$ & - & - & - & - \\
IATA & 0.696 & 0.487 & 0.576 & $0.914 \dagger$ & - & - & - \\
PIBI & 0.760 & 0.528 & 0.700 & 0.730 & $0.799 \dagger$ & - & - \\
MPD & 0.755 & 0.584 & 0.794 & 0.605 & 0.711 & $0.848 \dagger$ & - \\
MED & 0.664 & 0.695 & 0.704 & 0.551 & 0.628 & 0.673 & $0.853 \dagger$ \\
\hline
\end{tabular}

Note: Non-square root values are the correlation values between constructs.

ICP, Interaction and Cooperation through Platform; IIA, Internet Information Acquisition; ISC Internet Strategic Capability; IATA, Internet Advanced Technology Application; PIBI, Performance of Internet Brand Innovation; MPD, Mining Potential Demands; MED, Meeting Existing Demands.

$\dagger$, square root values of the AVE of each construct.

TABLE 5: Significance testing results of structural model path coefficients.

\begin{tabular}{lcccc}
\hline Paths & $\begin{array}{c}\text { Path } \\
\text { coefficients }\end{array}$ & $t$-values & $p$-values & $\begin{array}{c}\text { Significance } \\
\text { levels }\end{array}$ \\
\hline $\begin{array}{l}\text { Internet information acquisition } \\
\rightarrow \text { Meet existing demands }\end{array}$ & 0.696 & 17.077 & 0.000 & $* * *$ \\
$\begin{array}{l}\text { Internet information acquisition } \\
\rightarrow \text { Mining potential demands }\end{array}$ & 0.587 & 11.763 & 0.000 & $* * *$ \\
$\begin{array}{l}\text { Meet existing demands } \rightarrow \\
\text { Performance of internet brand } \\
\text { innovation }\end{array}$ & 0.140 & 2.382 & 0.017 & $*$ \\
$\begin{array}{l}\text { Mining potential demands } \rightarrow \\
\begin{array}{l}\text { Performance of internet brand } \\
\text { innovation }\end{array}\end{array}$ & 0.259 & 3.268 & 0.001 & $* *$ \\
$\begin{array}{l}\text { Interaction and cooperation } \\
\text { through platform } \rightarrow \text { Performance } \\
\text { of internet brand innovation }\end{array}$ & 0.474 & 5.760 & 0.000 & $* * *$ \\
\hline
\end{tabular}

of internet brand innovation

Note: Bootstrap confidence intervals for $5 \%$ probability of error $(\alpha=0.05)$.

$* p<0.05 ; * * p<0.01 ; * * * p<0.001$.

TABLE 6: Mediator analysis.

\begin{tabular}{|c|c|c|c|c|c|}
\hline \multirow[t]{2}{*}{ Mediating effects } & \multirow[t]{2}{*}{ Paths } & \multirow[t]{2}{*}{$t$-value } & \multicolumn{3}{|c|}{$z$-value } \\
\hline & & & $\begin{array}{c}\text { Sobel } \\
\text { test }\end{array}$ & $\begin{array}{c}\text { Aroian } \\
\text { test }\end{array}$ & $\begin{array}{c}\text { Goodman } \\
\text { test }\end{array}$ \\
\hline \multirow[t]{2}{*}{$\mathrm{IIA} \rightarrow \mathrm{MED} \rightarrow \mathrm{PIBI}$} & $\| \mathrm{A} \rightarrow \mathrm{MED}$ & 17.077 & $2.359 *$ & $2.355^{*}$ & $2.363^{*}$ \\
\hline & $\mathrm{MED} \rightarrow \mathrm{PIBI}$ & 2.382 & - & - & - \\
\hline \multirow[t]{2}{*}{$\mathrm{IIA} \rightarrow \mathrm{MPD} \rightarrow \mathrm{PIBI}$} & $\mathrm{IIA} \rightarrow \mathrm{MPD}$ & 11.763 & $3.149 * *$ & $3.138 * *$ & $3.159 * *$ \\
\hline & $\mathrm{MPD} \rightarrow \mathrm{PIBI}$ & 3.268 & - & - & - \\
\hline
\end{tabular}

IIA, Internet Information Acquisition; MED, Meeting Existing Demands; MPD, Mining Potential Demands; PIBI, Performance of Internet Brand Innovation. ${ }^{*} p<0.05 ;{ }^{* *} p<0.01 ;{ }^{* * *} p<0.001$.

TABLE 7: Moderator analysis.

\begin{tabular}{lcccc}
\hline Paths & $\begin{array}{c}\text { Path } \\
\text { coefficients }\end{array}$ & $t$-values & $p$-values & $\begin{array}{c}\text { Significance } \\
\text { levels }\end{array}$ \\
\hline $\begin{array}{l}\text { Moderating effect } 1 \rightarrow \text { Meeting } \\
\text { existing demands }\end{array}$ & 0.022 & 0.432 & 0.666 & NS \\
$\begin{array}{l}\text { Moderating effect } 2 \rightarrow \text { Mining } \\
\text { potential demands }\end{array}$ & 0.068 & 1.830 & 0.067 & $*$ \\
$\begin{array}{l}\text { Moderating effect 3 } \rightarrow \text { Meeting } \\
\text { existing demands }\end{array}$ & 0.050 & 1.088 & 0.277 & NS \\
$\begin{array}{l}\text { Moderating effect 4 } \rightarrow \text { Mining } \\
\text { potential demands }\end{array}$ & 0.081 & 2.330 & 0.020 & $* *$ \\
\hline
\end{tabular}

Note: Bootstrap confidence intervals for $10 \%$ probability of error $(\alpha=0.1)$.

NS, not significant.

${ }^{*} p<0.10 ;{ }^{* *} p<0.05 ;{ }^{* * *} p<0.01$

information acquisition and meeting existing demands is not significant, indicating that $\mathrm{H} 2 \mathrm{a}$ is not supported. Internet strategic capability positively moderates the relationship between Internet information acquisition and mining potential demands, indicating that $\mathrm{H} 2 \mathrm{~b}$ is supported. The moderating effect of the Internet advanced technology application on the relationship between Internet information acquisition and meeting existing demands is not significant, indicating that $\mathrm{H} 3 \mathrm{a}$ is not supported. Internet advanced 
technology application positively moderates the relationship between Internet information acquisition and mining potential demands indicating that $\mathrm{H} 3 \mathrm{~b}$ is supported.

Hypothesis 2a is not supported for the following reason: Internet strategic capability can help companies identify potential market opportunities and risks from massive information quickly and accurately and focus deeply on mining potential demands rather than blind expansion. This capability is more relevant to future and unknown fields than existing and known fields. Hypothesis $3 a$ is not supported for the following reasons: the main purpose of applying Internet advanced technology to conduct brand innovation is to constantly create new blue oceans, mine potential demands that even consumers are unaware of themselves and overturn existing products, markets or business models, whereas companies have few motivations to apply Internet advanced technology to meet existing demands.

\section{Explanatory power test}

When focusing on marketing issues, an $R^{2}$ value of $0.75,0.50$ or 0.25 can be, respectively, described as having substantial, moderate or weak explanatory power (Hair et al., 2014). The $R^{2}$ value of performance of Internet brand innovation is 0.631 , the $R^{2}$ value of meeting existing demands is 0.628 and the $R^{2}$ value of mining potential demands is 0.681 indicating that our model has strong explanatory power.

\section{Conclusion}

\section{Theoretical contributions}

Firstly, Internet brand innovation is defined as follows: 'Companies carry out brand innovations based on the Internet, which result in fundamental changes to existing products, marketing or business model practices'. Based on the two driving factors of innovation, the existing research has proposed that brand innovation included two models: marketing innovation and product or technology innovation. We supplement a new model for Internet brand innovation: business model innovation. In addition, existing literature has not reached a consensus on the extent to which brand innovation affects existing practices and markets. We find that only innovations that result in fundamental changes to existing practices and markets can be counted as Internet brand innovations. Thus, this article defines the concept of Internet brand innovation more comprehensively and accurately, which lays the foundation for future research.

Secondly, Internet brand innovation is a process that involves five core concepts: Internet information acquisition, Internet information application (meeting existing demands and mining potential demands), Internet advanced technology application, Internet strategic capability and interaction and cooperation through platform. The influencing mechanism of these core concepts on performance is as follows: Internet information acquisition $\rightarrow$ Internet information application (meeting existing demands and mining potential demands) $\rightarrow$ performance (main influencing path). Internet advanced technology application and Internet strategic capability can enhance the positive impact of Internet information acquisition on mining potential demands (moderating effects). Interaction and cooperation through platform positively affect performance. Research has proposed that social media brand innovation involved three core concepts: knowledge acquisition, knowledge application and strategic capability. We supplement two new core concepts for Internet brand innovation: advanced technology application and interaction and cooperation through platform. The existing literature had not examined the main effect of 'knowledge acquisition from social media $\rightarrow$ social media knowledge application $\rightarrow$ performance', nor had it examined the impact of social media brand innovation on performance. Based on absorptive capacity theory, we find a main influencing path of 'Internet information acquisition $\rightarrow$ Internet information application $\rightarrow$ performance'; we also confirm the moderating effects of Internet strategic capability and advanced technology application, as well as the important influence of interaction and cooperation through platform on performance. Thus, this article initially opens the black box of 'how companies can conduct Internet brand innovation better to improve performance'.

Thirdly, for Internet companies, mining potential demands is more important than meeting existing demands and disruptive innovation is more important than incremental innovation. Disruptive innovation or incremental innovation - which kind of innovation model can usher in higher returns? The answer to this controversial question may vary according to industry, enterprise type, and the nature of the enterprise (Chang, Franke, Butler, Musgrove, \& Ellinger, 2014; Oke, Burke, \& Myers, 2007). In the previous definition of Internet brand innovation, we highlighted the importance of disruptive innovation. Now, the results of quantitative research also show that the total effect of mining potential demands on the performance of Internet brand innovation (0.259) is stronger than that of meeting existing demands (0.138). What's more, Internet advanced technology application and Internet strategic capability can only enhance the positive impact of Internet information acquisition on mining potential demands. These conclusions solve the controversy of whether disruptive innovation or incremental innovation can bring higher returns to a certain extent.

\section{Practical implications}

Firstly, for Internet companies, mining potential demands and disruptive innovation is more important. In our investigation process, we found that many industries closely related to the Internet (such as online ride-hailing, live streaming and short video creation) are rapidly changing, and few successful business models are fully universal and consistently feasible. Many Internet companies are 'crossing the river by feeling the stones' because they face new situations. Their current strategies and businesses differ from their original ideas. 'There is no future in imitating business 
models of giants when they have already established their ecosystems', according to the founder of 360 Company. Only by constantly mining potential demands, discovering new blue oceans, and solving the pain points of industry better and faster than competitors can companies establish their own ecosystems and ultimately improve performance. In summary, Internet companies should explore new avenues.

Secondly, continuous innovation is important; however, blind innovation is dangerous. Internet companies should conduct brand innovation activities according to their strategic direction and choice. Internet companies should adhere to Huawei's 'principle of pressure', allocating resources to the main channel in a way that exceeds that of their major competitors. Furthermore, Internet companies should concentrate their resources to achieve breakthroughs in key fields. However, 'Internet companies should oppose blind innovations', as Huawei's founder said. Jack Welch, former CEO of GE, emphasised that the company has to be either No. 1 or No. 2 in every industry it enters or walk away from it. Therefore, we advise Internet companies to avoid blind innovations, diversification and expansion. In summary, Internet companies should focus on their main channels for conducting continuous brand innovations.

Thirdly, in the process of Internet brand innovation, we suggest that companies encourage users to participate in the entire process and conduct open cooperation with partners to build win-win ecosystems. Encouraging users to participate in the process of product development, communication, sales and after sales. 'Xiaomi is selling a sense of participation, this is the real secret behind Xiaomi's success', as mentioned by the Xiaomi's founder. Another example is building up a boundaryless company as Jack Welch did with GE. Furthermore, in the mobile Internet era, the 'boundaryless management' can be extended outside of the company, that is, by carrying out open cooperation with partners through Internet platform. Thus, Internet companies should build win-win ecosystems and co-create value with stakeholders (Gamble, Clinton, \& Diaz-Moriana, in press).

\section{Limitations and future prospects}

Firstly, owing to limited resources, our interviewees were mainly Internet start-ups that lack first-hand information on the founders and senior executives of the largest Internet companies such as Alibaba, Tencent and Baidu. These business elites may provide important insights into our research topics from their unique perspectives. However, without face-to-face communication with these business elites, we cannot co-construct knowledge with them (Marshall \& Rossman, 2011). If scholars can address this limitation in the future, more valuable information may be obtained. Secondly, we selected Honor mobile phone as our research object and the company's employees as our survey respondents. Thus, the universality of our research conclusions should be further verified. Scholars should collect data from other industries and companies to further verify, supplement and enrich our conclusions.

\section{Acknowledgements}

We would like to thank Professor Zhang Xin-Rui for inspiring our thoughts, thank the anonymous reviewers for their insightful comments and suggestions, and thank editors for their kindly help and support.

\section{Competing interests}

The authors declare that they have no financial or personal relationships that may have inappropriately influenced them in writing this article.

\section{Authors' contributions}

Y.Y-W. and T.X-B. conceived of the presented idea. Y.Y-W. developed the theory and performed the computations. T.J-B. and L.P. verified the analytical methods. L.J-P. encouraged Y.Y-W. to investigate typical cases and supervised the findings of this work. All authors discussed the results and contributed to the final manuscript.

\section{Ethical considerations}

This article followed all ethical standards for carrying out research.

\section{Funding information}

This work was supported by the National Natural Science Foundation of China (grant number 71802005), the National Natural Science Foundation of China (grant number 71832015), the Beijing Social Science Foundation (grant number 17GLC068), the National Natural Science Foundation of China (grant number 71702002), the Beijing Natural Science Foundation (grant number 9182003), and General Program of Social Science Plan of Beijing Municipal Education Commission (grant number SM201910009007).

\section{Data availability}

The data that support the findings of this study are available on request from the corresponding author. The data are not publicly available owing to restrictions set out in a confidentiality agreement with Huawei Technologies Company.

\section{Disclaimer}

The views and opinions expressed in this article are those of the authors and do not necessarily reflect the official policy or position of any affiliated agency of the authors.

\section{References}

Beverland, M.B., Napoli, J., \& Farrelly, F. (2010). Can all brands innovate in the same way? A typology of brand position and innovation effort. Journal of Product Innovation Management, 27(1), 33-48. https://doi.org/10.1111/j.1540-5885. 2009.00698.x 
Camisón, C., \& Forés, B. (2010). Knowledge absorptive capacity: New insights for its conceptualization and measurement. Journal of Business Research, 63(7), 707-715. https://doi.org/10.1016/j.jbusres.2009.04.022

Chang, W., Franke, G.R., Butler, T.D., Musgrove, C.F., \& Ellinger, A.E. (2014) Differential mediating effects of radical and incremental innovation on market orientation-performance relationship: A meta-analysis, Journal of Marketing Theory and Practice, 22(3), 235-250. https://doi.org/10.2753/MTP10696679220301

Chimhundu, R., Hamlin, R.P., \& McNeill, L. (2010). Impact of manufacturer brand innovation on retailer brands. International Journal of Business and Management, 5(9), 10-18. https://doi.org/10.5539/ijbm.v5n9p10

Choi, S.Y., Lee, H., \& Yoo, Y. (2010). The impact of information technology and transactive memory systems on knowledge sharing, application, and team performance: A field study. MIS Quarterly, 34(4), 855-870. https://doi. org $/ 10.2307 / 25750708$

Codron, J.M., Grunert, K., Giraud-Heraud, E., Soler, L.G., \& Regmi, A. (2005). Retail sector responses to changing consumer preferences. New Directions in Global Food Markets, 794, 32-46.

Cohen, W.M., \& Levinthal, D.A. (1990). Absorptive capacity: A new perspective on learning and innovation. Administrative Science Quarterly, 35(1), 128-152. https://doi.org/10.2307/2393553

Creswell, J.W. (1998). Qualitative inquiry and research design: Choosing among five traditions. Los Angeles, CA: Sage Publications.

Danneels, E. (2002). The dynamics of product innovation and firm competences. Strategic Management Journal, 23(12), 1095-1121. https://doi.org/10.1002/smj.275

Foss, N.J., Laursen, K., \& Pedersen, T. (2011). Linking customer interaction and innovation: The mediating role of new organizational practices. Organization Science, 22(4), 980-999. https://doi.org/10.1287/orsc.1100.0584

Gamble, J.R., Clinton, E., \& Diaz-Moriana, V. (in press). Broadening the business mode construct: Exploring how family-owned SMEs co-create value with external stakeholders. Journal of Business Research. https://doi.org/10.1016/j.jbusres. 2020.03.034

García-Sánchez, E., García-Morales, V.J., \& Bolívar-Ramos, M.T. (2017). The influence of top management support for ICTs on organisational performance through knowledge acquisition, transfer, and utilisation. Review of Managerial Science, 11(1), 19-51. https://doi.org/10.1007/s11846-015-0179-3

Grigoriou, N., Davcik, N., \& Sharma, P. (2016). Exploring the influence of brand innovation on marketing performance using signaling framework and resourcebased theory (RBT) approach. In M.W. Obal, N. Krey, \& C. Bushardt (Eds.), Let's get engaged! Crossing the threshold of marketing's engagement era (pp. 813-818). Cham: Springer.

Hair, J.F., Jr., Hult, G.T.M., Ringle, C., \& Sarstedt, M. (2014). A primer on partial least squares structural equation modeling (PLS-SEM). Los Angeles, CA: Sage Publications.

Hinkin, T.R. (1995). A review of scale development practices in the study of organizations. Journal of Management, 21(5), 967-988. https://doi. org/10.1177/014920639502100509

Keller, K.L. (2013). Strategic brand management: Building, measuring and managing brand equity. Boston, MA: Pearson Education.

Kim, Y.J., \& Han, J.Y. (2014). Why smartphone advertising attracts customers: A mode of web advertising, flow, and personalization. Computers in Human Behavior 33(2), 256-269. https://doi.org/10.1016/j.chb.2014.01.015

Kvale, S. (1996). Interviews: An introduction to qualitative research interviewing. Thousand Oaks, CA: Sage Publications.

LeBlanc, L.A., Heinicke, M.R., \& Baker, J.C. (2012). Expanding the consumer base for behavior-analytic services: Meeting the needs of consumers in the 21st century. Behavior Analysis in Practice, 5(1), 4-14. https://doi.org/10.1007/ BF03391813

Lee, T.W. (1999). Using qualitative methods in organizational research. Los Angeles, CA: Sage Publications.

Marshall, C., \& Rossman, G.B. (2011). Designing qualitative research. Los Angeles, CA Sage Publications.
Marvel, M.R., \& Lumpkin G.T. (2007). Technology entrepreneurs' human capital and its effects on innovation radicalness. Entrepreneurship Theory and Practice, 31(6), 807-828. https://doi.org/10.1111/j.1540-6520.2007.00209.x

Narver, J.C., Slater, S.F., \& Maclachlan, D.L. (2004). Responsive and proactive market orientation and new-product success. Journal of Product Innovation Management, 21(5), 334-347. https://doi.org/10.1111/j.0737-6782.2004. 00086.x

Nguyen, B., Yu, X., Melewar, T.C., \& Chen, J. (2015). Brand innovation and social media: Knowledge acquisition from social media, market orientation, and the moderatin role of social media strategic capability Industrial Marketing Management, 51(11), 11-25. https://doi.org/10.1016/j.indmarman.2015.04.017

Nguyen, B., Yu, X., Melewar, T.C., \& Gupta, S. (2016). Critical brand innovation factors (CBIF): Understanding innovation and market performance in the Chinese hightech service industry Journal of Business Research, 69(7), 2471-2479. https://doi. org/10.1016/j.jbusres.2016.02.016

Nieves, J., \& Diaz-Meneses, G. (2016). Antecedents and outcomes of marketing innovation: An empirical analysis in the hotel industry. International Journal of Contemporary Hospitality Management, 28(8), 1554-1576. https://doi. org/10.1108/IJCHM-11-2014-0589

Oke, A., Burke, G., \& Myers, A. (2007). Innovation types and performance in growing UK SMEs. International Journal of Operations \& Production Management, 27(7), 735-753. https://doi.org/10.1108/01443570710756974

Podsakoff, P.M., Mackenzie, S.B., Lee, J.Y., \& Podsakoff, N.P. (2003). Common method biases in behavioral research: A critical review of the literature and recommended remedies. Journal of Applied Psychology, 88(5), 879-903. https://doi. org/10.1037/0021-9010.88.5.879

Salavou, H., \& Lioukas, S. (2003). Radical product innovations in SMEs: The dominance of entrepreneurial orientation. Creativity and Innovation Management, 12(2), 94-108. https://doi.org/10.1111/1467-8691.00272

Sammour, A., Chen, W., Balmer, J.M., Botchie, D., \& Faraday, J. (2020). Crafting the forever now: Corporate heritage brand innovation at John Lewis Partnership. Strategic Change, 29(1), 115-126. https://doi.org/10.1002/jsc.2315

Slotegraaf, R.J., \& Pauwels, K. (2008). The impact of brand equity and innovation on the long-term effectiveness of promotions. Journal of Marketing Research, 45(3), 293-306. https://doi.org/10.1509/jmkr.45.3.293

Song, H., and Liu, H. (2017). Predicting tourist demand using big data. In Z. Xiang \& D.R. Fesenmaier (Eds.), Analytics in smart tourism design (pp. 13-29). Cham: Springer.

Spiegel, O., Abbassi, P., Zylka, M.P., Schlagwein, D., Fischbach, K., \& Schoder, D. (2016). Business model development, founders' social capital and the success of early stage internet start-ups: A mixed-method study. Information Systems Journal, 26(5), 421-449. https://doi.org/10.1111/isj.12073

Stock, R.M., Six, B., \& Zacharias, N.A. (2013). Linking multiple layers of innovationoriented corporate culture, product program innovativeness, and business performance: A contingency approach. Journal of the Academy of Marketing performance: A contingency approach. Journal of the Academy of
Science, 41(3), 283-299. https://doi.org/10.1007/s11747-012-0306-5

Symon, G., \& Cassell, C. (1997). Qualitative methods and analysis in organizational research: A practical guide. Learning Organization, 40(3), 1164-1169.

Teece, D.J. (2007). Explicating dynamic capabilities: The nature and microfoundations of (sustainable) enterprise performance. Strategic Management Journal, 28(13) 1319-1350. https://doi.org/10.1002/smj.640

Van Nguyen, T., Zhou, L., Chong, A.Y.L., Li, B., \& Pu, X. (2020). Predicting customer demand for remanufactured products: A data-mining approach. European Journa of Operational Research, 281(3), 543-558. https://doi.org/10.1016/j.ejor 2019.08.015

Yu, X., Chen, Y., Nguyen, B., \& Zhang, W. (2014). Ties with government, strategic capability, and organizational ambidexterity: Evidence from China's information communication technology industry. Information Technology and Management 15(2), 81-98. https://doi.org/10.1007/s10799-014-0175-3

Zahra, S.A., \& George, G. (2002), Absorptive capacity: A review, reconceptualization, and extension. Academy of Management Review, 27(2), 185-203. https://doi. org/10.5465/amr.2002.6587995 